\title{
A critical look at Orientalism as envisaged in James Justinian Morier's Haji Baba of Ispahan
}

\author{
Akram Pouralifard \\ English department, Tabriz University, Tabriz, Iran \\ Tel: 00989143012786 E-mail: hpourali@tabrizu.ac.ir
}

Received: 04-02-2013

doi:10.7575/aiac.ijalel.v.2n.3p.196
Accepted: 01-04-2013

Published: 01-05-2013

URL: http://dx.doi.org/10.7575/aiac.ijalel.v.2n.3p.196

\begin{abstract}
This paper examines James Justinian Morier's The Adventures of Haji Baba of Ispahan in order to reveal various horizons of meaning as a result of four different readings of the novel. The entertaining effect is surveyed through the first reading. The satirical hue which tints the events and characters is disclosed through the second reading. The third reading looks at the objectives underlying the entertaining and satirical-corrective texture of the narrative via employing Edward W. Said's critical theory of 'Orientalist discourse'. And, finally, the fourth reading is an examination of the ambivalent attitude of the writer towards the cultural, ideological and social deportment of the Persians. The last reading has a focus upon the inadequacy of Said's monolithic opinion on Colonial discourse's look towards the East.
\end{abstract}

Keywords: horizons of meaning; different readings; Haji Baba of Ispahan; colonial discourse; Orientalism

\section{Introduction}

A critical reading of the texts concerning colonized peoples authored within the time of colonization or after it is revealing of the relations between the colonizer and the colonized. This relationship becomes more transparent through interrogating the representations of the native by the pen of the coloniser. This study is a critical review of James Justinian Morier's The Adventures of Haji Baba of Ispahan (1824). Morier (1780-1849) is among the authors whose works have enjoyed a worldwide appreciation from the intellectual world as they believe the novel provides a realistic and scholarly delineation of the Persian's culture, life style, disposition, and their theoretical and practical worldview. This review is an effort to critically examine the different layers of meaning in Haji Baba through four different readings .

The first reading of the review looks at the surface structure of the narrative resulting in the entertaining impression on the reader, while the second sees it in the light of the satirical air which is present all through the novel. The third reading discloses the objectives underlying the entertaining and satirical-corrective fabric of the novel in the light of $\mathrm{E}$. Said's idea of representation structured in his 'Orientalist discourse'. A review of this theory precedes my third reading which includes its main assumptions, points of strength, parts to be used in my analysis and the aspects not meeting the demands of my study. The fourth reading of the text reveals the ambivalent attitude of the writer toward the cultural, ideological and social manners of the Persians. There are instances in which the writer approves of the behavior, feelings, and beliefs of the protagonist and the minor characters. I have categorized these discrepancies into four parts which confirm the inadequacy of Said's theory in analyzing the Orientalist discourse of the text and the necessity of incorporating an auxiliary theory such as Bhabha's concept of 'ambivalence'.

The amount of written material in books, journals and introduction to the English editions of this work (13 editions) bears testimony to its popularity and power which gives me the chance to analyse it in a light other than it was formerly perceived_the genre of picaresque covered in an air of satire. What distinguishes this study from the former trends is that it surveys the orientalist ideology behind the satirical hue of the narrative. Additionally, it makes an attempt to reveal the inconsistencies wrapped in the satirical, corrective, and entertaining structure of the text. So, the last two perspectives could be considered novelties in the history of reception of the narrative, which marks the significance of this review.

The episodic structure of the novel has made the anti-hero its only factor of coherence which makes my review follow a thematic sketch instead of a chronological one.

\section{The first look; the entertaining phase}

2.1 The Adventures of Hajji Baba of Ispahan recounts, in the first person, the extraordinary adventures of its hero, the son of a barber from Isfahan who in the course of his many years of travel and adventure frequently changes guises and professions. He gets into trouble because of his own mischief and he manages to get out of it through his resourcefulness. He experiences sharp vacillations between poverty and wealth and between undeserved power and punishing powerlessness. His life is dictated in the main by a blind and fickle fate, which Hajji Baba seems to miraculously manage to turn each time to his own advantage. His gift is an inherent propensity for detecting 
opportunities, playing on the need and greed of others, and clinging to an amoral pragmatism for the sake of his own shifting and prurient desires, albeit with a belated sense of guilt toward his victims.

\section{The second look; the disclosure of satire;}

Underlying the entertaining events and scenes of the novel is a bitter criticism of Persians and their material and spiritual life style. This criticism is rendered in the biographical account of the protagonist's life through which the writer manages to picture Persians as rascals, cowards, villains and downright fools. He has depicted the Persians' culture as scandalously dishonest and decadent, and their society as violent.

Through the episodic chapters, the writer satirizes a society that is framed by superstition, backwardness, fanatically non-scientific ideas and unjustifiable naiveté. It is in chapter XI, for instance, that mothers rush to the deceitful dervish asking for "protection for their children against the devil eye, wives for a spell against the jealousy of their husbands, and warriors for talismans to secure them from harm in battle"(1895, p. 60). A major focus of the novel in satirizing the cultural vileness of Persians makes its presence known from the start. In chapter IX, Haji's friend entices him to be a water-carrier because he has "a great talent for cant and palaver and for laughing at one's beard" (1895, p. 54). The narrator in chapter IIL, states that "without a present nothing is ever accomplished in Persia" (1895, p. 216), and at the end of this part he reveals that the dervish after befriending, helping and teaching him, has finally robbed Haji of his money before taking his leave $(1895$, p. 216). This is the best possible arrangement of attitudes to picture an intricate and unpredictable character, one that tries to impart virtuous intentions but is finally defeated by an inherent and frenetic vice. The novelist draws a comparison between a Europe that is grounded on morality and a Persia that is culturally decadent. Through such a comparison he attempts to justify the corrective mission of the Europeans in Persia that seems to be the most important objective of his satirical creations in the novel.

\section{The third look; the ideology of Orientalism}

In his critical theory of Orientalism, E. W. Said argues that a harmless philological subspecialty as Orientalism has been transformed into a "capacity for managing political movements and administering colonies" (1979, p. 254) ${ }^{i}$. Said has tried to show that under the mask of the white man's civilizing mission in the Orient, Orientalism is employed to achieve the ends of imperialistic discourse in the region (1979, p. 254). So, methodologically, the basic theoretical assumption of this review comes from Edward Said's concept of 'representation' to probe the images and events which are implemented to serve the Orientalist discourse. Said defines Orientalist discourse as the "enormously systematic discipline by which European culture was able to manage... the Orient politically, sociologically, militarily, ideologically, scientifically and imaginatively during the post_Enlightenment period" (1979, p. 3).

As the conflict between the imperial power and its colonized subjects stands at the core of Said's argument, Marxism is, normally, the theoretical assumption he utilizes to develop his idea. The concepts of 'center' and 'periphery', and 'self' and 'other' are of crucial importance in his theory. Said explains the two particularities of the white man, i. e. making 'generalizations' and creating 'the field to demand', to conclude that the white man creates categories such as blacks, yellow-skinned, Arabs, Semites,... so that he can find the field to demand. For instance, the white man speaks of the colored or the Occidental can address the Oriental. The practical consequent of such an approach is categorizing the Arabs as a "collective self-consistency" with "centuries of experience and no wisdom" (1979, pp. 229-30) which justifies the colonizing presence of the imperial power in the Eastern lands.

The contribution of Said's theory to the Orientalist assumptions is that it brings to light a new dialectic which authorizes the "white man" to make the "contemporary history of the Orient" (1979, p. 238). This is a new form of Orientalist discourse that presents a vision of the contemporary Orient which "implicates definition of the object with the identity of the person defining" (1979, p. 247) or Said's concept of 'representation'.

Said explains the process through which the concept of 'representation' is produced. He uses three terms of 'style', 'expertise', and 'vision'. The style of the modern Orientalism, he argues, sees the present and the origin together, the best embodiment of which is to be found in Muslims and Semites. The use of this special style, as he explains, brings about the expertise of the Orientalist that is based upon an incontrovertible collective truthfulness, albeit there is no clue to prove it (1979, p. 237). He concludes that this expertise utilizes generalizations about the 'other' which in turn, authorizes the Orientalist to "act, to promise, and recommend public policy for preserving the Orient and Islam under the control of the white man"( 1979, p. 238). He introduces the concept of 'vision' in the last stage of this process which signifies the stability of the Oriental and its lack of competence and tendency towards any growth and dramatic movement throughout history. The final product of this procedure, Said concludes, is 'representation' which "presents a vision of the contemporary Orient, not as narrative but as all complexity, problematic, betrayed hope_with the white Oriental author as its prophetic, articulate definition"(1979, p. 239).

The theory's strength lies in its methodology of analysis seeking to unfold the political and psychological strategies of domination. Its idea of 'representation' gives way to the political analysis of literature and culture and dismantles the neglected fact that the twentieth century Orientalism reveals more the fantasies of the West about the East (1979, p. 247). I will discuss Said's theory's weakness in my fourth reading of the text as this part is to suggest the strategies to rectify the shortcomings of the theory.

Analysing the Orientalist ideology and Orientalist discourse is of central significance in this study. Through such an analysis, I will examine the validity of representation concerning the cultural and ideological dimensions of Persian life produced through the mind cast of an Orientalist author. 
Considering the rule's of Said's Orientalism, the theme of the novel is that the Persian 'other' is in need of being civilized and humanized by the European 'self', in his both material and spiritual life. The author of Haji Baba has tried to present a general picture of corruption of the Persians in their moral, cultural, and religious life. This image implies the inferiority of the nation and the need for their correction by the superior Europeans. Now the question is that to what extent this picture can be valid. As the ideology behind the plot of this novel is legitimizing the West's moral, cultural, and ideological dominance over the Orient, the reliability of the novel's representations according to the critical assumptions of Orientalism is of high significance in the third reading the interpretation stage.

The Orientalist ideology behind the novel finds a bed with the very beginning of the story that is the title. In Islamic canon, Haji is the title bestowed on Muslims who have performed the pilgrimage to Mecca, signifying religious devotion and accomplishment, and Baba, in Persian terminology is used for grandfather indicating responsible authority and guardianship. The main character of the novel, a trickster, from a satirical standpoint, is the most proper choice to be designated by the two loaded terms to serve the intentions of the ii writer. Morier's display of Persian vagaries serves as a reassurance of Europe's cultural and moral superiority and the civilizing mission of the imperial powers following the objectives of Orientalist discourse_a self-image that begs for Westernizing corrections.

The representation of a morally decadent and culturally backward society proceeds to the first chapter in fourth line of which Haji's father is highlighted for the cruelty of abandoning his young wife for sterility and his second father-in-law grants his daughter to him just because the latter, a dexterous barber, has shaved the former's head "with so much success" (1895, p. 26). The new father-in-law is a money changer who "although noted for clipping money and passing it for lawful, affected to be a saint" $(1895$, p. 26), and Haji's father undertakes a pilgrimage to Karbala not for its sacredness but firstly, to "get rid of the importunities of his first wife" and secondly, to "acquire the good opinion of his new father-in-law" (1895, p. 26).

The recurrent structure of ridiculing the hypocritical Persian Muslims, regardless of their religious sect, for pretending to faith in order to secure their worldly interests is a wide-ranging mechanism to develop the theme of the novel. Osman Aga, a Sunni merchant, is introduced as a "good Muslim" who secretly drinks wine and denounces "eternal perdition" to those who openly indulge in it (1895, p. 28). A famous clergyman of high rank, the emblem of Islam, is referred to as a crafty hypocrite having his "exterior fitted up for the purposes of the world" and his interior "devoted to himself and his enjoyments" (1895, p. 240). This denigration of Persian Muslims for being double-crossers reaches its peak when the barbarous Muslims led by a clergy, enter the church and the houses of Christians and ruin everything including books and crosses, thinking that the cause of long lasting draught is the wine drinking of the Christians and they [Muslims] return to reason only when an Armenian enters the place accompanied by an officer from the king (1895, p. 253).

The misrepresentation of Persians and their ideology in Haji Baba, done intentionally or not, backs the ideology of Orientalism. The writer, at times, imparts an impression of adversity of the Orientalist discourse towards Islamic doctrine. He, through the mouth of a Persian Muslim, claims that it is not the divine ordinance to appoint the prophet of Islam for the people's leadership but impudence and benefiting the addressee's gullibility and getting their trust which makes a great prophet capable of miraculous practices $(1895$, p. 56).

As the worldly context of European life makes it difficult or impossible to imagine a life that is an integration of spirituality and sensuality, the religious cities of Persia are seen as having deprived their settlers of the worldly pleasure and the only concern of their life is issuing decrees of death on disbelievers in Islam. Life in these cities is rendered as a compulsion making people dextrous shammers who pretend to religiosity just to save their personal interests; read their religious book out of the compelling of the society, whether to understand it or not; and never perform their religious acts out of the demand of their soul, but just to fortify their social status. This is what I mean by the intentional adversity of the Occidental imperialistic discourse towards the Islamic ideology recurrently implemented throughout the novel.

According to Said's Orientalism, Morier presents Persia as a panoramic stage of social, moral, religious, political and cultural corruption and stagnation. He offers a representation of this country which accords with all the Western Stereotypes of Oriental disorder, cunning, degeneracy and debasement. The Persians are represented as having very little domestic affection, experiencing pleasure only through immoral acts such as robbery and taking bribes. The novel displays Persians as rascals, footling villains, and cowards, and portrays the Persian culture and Islamic ideology as dishonest, decadent and incompetent in meeting the needs of the nation. His hostile and satirical overtone toward the Persian culture and Islamic heritage is so adeptly covered in the form of biography of a native that certifies Europe's cultural, moral and ideological superiority and its civilizing mission in Persia.

\section{The fourth look; examining discrepancies}

A fourth reading of the book reveals the instances contradicting the ideology of Orientalism as the novel's deep structure. Up to the third reading, the concepts of Orientalist ideology prove to be advisable in unearthing the goals behind the satirical and aesthetic outline of the novel. A more ruminative study of the text, however, introduces the horizon of inconsistencies between the facts of the story and the goals behind them.

In spite of the fact that Edward Said's 'Orientalism' has proved to be highly competent in analyzing the discourse of Imperialism and Orientalism, his excessively negative opinion of the ideology of Orientalism has made him neglect the ambivalences in the discourse of colonialism. In implementing this theory to examine Morier's Haji Baba of Ispahan for its Orientalist themes, I have come across the ideas which fail to correspond to Said's theory of Orientalist 
discourse. The classification I have considered for these ideas comes in the following. To elaborate each of the categories, I will provide evidence from the pertinent texts.

\section{The discrepancies in the primary source}

\subsection{The novelist's positive ideas of the protagonist}

In the following extract, the protagonist confesses his wrong doings and decides to live a life of honesty and truthfulness:

I determined to wait the arrival of the poet, and through his interference to endeavour to get into some situation, where I might gain my bread honestly, and acquire a chance of advancing myself in life, without having recourse to the tricks and frauds which I had hitherto practised: for I was tired of herding with the low and the vulgar; and I saw so many instances before me of men rising in the world, and acquiring both riches and honour, who had sprung from an origin quite as obscure as my own, that I already anticipated my elevation, and even settled in my own mind how I should act when I was a prime vizier. $(1895$, p. 78$)$

The benevolence displayed by the protagonist toward others contradicts the presumption of colonizer and colonized relationship in Orientalism. In spite of being a chief executioner, Haji shows a feeling heart and sympathises with a young man and woman and assists them in their distress:

Thanks to Heaven, you are not one of the Serdar's officers! I entreat you to befriend me, and my lamentable tale may perhaps induce you to take us under your protection.

This appeal to my feelings was unnecessary: the countenance and appearance of the youth had excited great interest in my breast, and I immediately lent myself to his wishes, telling him that we would, without delay, convey his sick friend to the village, and then, having heard his story, settle what to do for him. (1895, p. 148)

The following is indicative of Haji's affections to his beloved and the regret he feels for her pains. He, moreover, shows a sincere sense of faith by saying his prayer in his seclusion and being revived by doing so while he has no personal interest in mind:

Pulling out the handkerchief from my breast, still wet with the blood of the unfortunate Zeenab, I contemplated it with feelings of the most bitter anguish; then spreading it before me on her grave, I went through a ceremony to which I had long been unaccustomed,- - I said my prayers. Refreshed by this act, and strengthened in my resolutions of leaving Tehran, I tore myself away, and stept valiantly onwards towards Ispahan. (1895, p. 189)

The protagonist's downright confessions to his dishonesty contradict his attributions of roguery. On their departure to invade Isfahan he says:

For my part, I felt that nature had never intended me for a warrior, and although I thought that I could keep up appearances as well as most men in my predicament, and indeed I believe did act my part so perfectly, as to make both my master and his companions believe that they had got a very Rustam in me, yet I dreaded the time when I should be put to the trial. (1895, p. 40)

\subsection{The novelist's positive ideas of the other characters}

The positive characteristics ascribed to the minor characters confirm Morier's ambivalent opinion about the Persians. The following is the unadulterated, affectionate well-wishing of Osman Agha, the old companion of Haji Baba, when he is seeing off Haji for a journey:

But when I took my leave of the old Osman, I found him unchanged, and every word he spoke showed that his affection for the son of the barber of Ispahan was the feeling which ever actuated his conduct towards me. 'Go, my son,' said he, as he parted from me, 'whether you be a prisoner with the Turcomans, or a priest, or a seller of pipe-sticks, or a Turkish aga, or a Persian mirza; be you what you may. I shall always put up my prayers for your prosperity, and may Allah attend your steps wherever you go. (1895, p. 322)

The following relates the personality of Mirza Firouz, the Persian ambassador to the British court:

$\mathrm{He}$ is gifted with the most overwhelming powers of speech, which always are sure to get him out of the scrapes into which his indiscreet use of them very frequently leads him. To his servants and followers he is kind and the contrary, by turns. Sometimes he permits them to do and say everything which they choose, at others, he keeps them at a most chilling distance. But, on the whole, he is easy of access, of agreeable commerce, of most fascinating manners, and of a joyous and sociable nature. (1895, p. 312, emphasis mine)

Although the Persian commanders are normally described as startlingly despotic and corrupt, they, at intervals, are displayed as officials with a sense of responsibility. He describes one of the commanders as "a figure commanding, but coarse and looking his office greatly to the advantage of the peace of the city". $(1895$, p. 134)

The image of the Persian culture which the novel provides is, generally, decadent and corrupt. The following extract, contrarily, shows Morier's high opinion and articulate appreciation of this culture.

The moment I recognized him, I let go his beard, of which I had got a fast hold, and, owing to that habit of respect which we Persians show to our parents, would have kissed his hand and stood before him; but my life was in danger if I appeared to flinch, so I continued to struggle with him, and in order to show myself in 
earnest, pretending to beat him, I administered my blows to a mule's pack-saddle that was close to where he lay. (1895, p. 42, emphasis mine)

Another example shows Morier's attempt to picture the despotic character of Persians by drawing a comparison between a commander and a brute: “...his character corresponded to his looks; for no law, human or divine, ever stood in the way of his sensuality; and when his passions were roused, he put no bounds to his violence and cruelty (1895, p. 172). Yet, it takes no long that the writer marks him as "affable to his inferiors", "remarkable for his hospitality", and "frank and open in his demeanour" (1895, p. 172).

Morier introduces the governing system in Persia as a corrupt one in which no appointment is done without a gift for the chief: "for when he found that I was to be installed in my office without making him a present, there was no end to the difficulties which he threw in my way." (1895, p. 134). The protagonist, however, is severely punished on the spot when an official executioner finds him cheating people in his tobacco trade that is contradictory to the image displaying the corrupt administrative system in Persia:

At length, wretch of an Ispahani!' said he, 'I have caught you-you, that have so long been poisoning the people of Meshed with your abominable mixtures. You shall receive as many strokes on your feet as you have received shahies for your pipes. Bring the felek, said he to his officers, 'and lay on till his nails drop off.' . (1895, p. 67)

The protagonist, a Persian, exposes human folly and attacks the hypocrisy and stupidity of those who want to enjoy the respect of the majority. The human tendency to find fault with, and mock, those in power is a major focus of interest for Haji Baba. He is the one who severely exposes and ridicules the politicians, priests and men of learning. So, the writer attributes the wit to see the faults of others and the ability to put it into a satirical framework with the corrective ends in mind to the protagonist who is a Persian and is worth of appreciation for what he sees and does.

\section{The discrepancies from the secondary sources}

\subsection{The novelist's positive ideas of the Persians in his other works}

Morier demonstrates positive opinion of the Persians in his other works. In his A Journey Through Persia, Armenia, and Asia Minor to Constantinople, in the year 1808 and 1809, he says: "we regarded them [the Persians] with the liveliest gratitude, and felt relieved by finding among the strangers all the heart and principle of countrymen and brothers" (1812, p. 128).

\subsection{The Oriental critics' confirmation of the novels' factual presentation of the cultural, social, political and ideological aspects of Persian life}

In addition to the two aforementioned facts which display the ambivalence of the Orientalist discourse toward the Orient, the excessively one-sided nature of Said's theory is highlighted by Persian critics. They appreciate Morier's judgments passed on the social, cultural and political situation of the country. A review of the history of reception by Persian critics of Haji Baba will support the claim. Mirza Agha Kahn Kirmani ${ }^{\text {iii }}$, (as cited in Bayat-Phillip, 1980, p. 47) writes of Haji Baba:

The English writer who has written this book has intended to depict all types and classes of Persians from the oppressor to the oppressed, Dervishes, Sufis, the ascetic and the merchant. He has depicted the manners and temperament of the Persians so that they may be informed of the foibles of their national character. He has written this book so that it may serve as a lesson and the Persians may feel disgusted at themselves and educate themselves to behave well.

Said's theory assesses Morier's novel as a trial to construct Persia as a habitat of rogues, where the order of good government and civilization is disrupted. This evaluation is questioned at times by the Persian critics confirming the historical facts of the novel concerning the ruling system and the moral codes of Persia. Yahya Aryanpour ${ }^{\text {iv }}$ says in this regard:

Morier did not intend to speak of Persia's glorious past and the positive qualities of the Persians. We are not offended by his depiction of bribery and sham piety because these were (and regretfully still are), the afflictions of governmental and religious organizations and as the writer has rightly observed, several high rank officials and religious dignitaries were (and still are) polluted with bribery and dissimulation. However, he has done injustice by exaggerating such faults and making exaggerations. (1997, p. 398)

\section{Conclusion}

This review is an attempt to survey James Justinian Morier's attitudes towards the Persians rendered in his The Adventures of Haji Baba of Ispahan. It aims at uncovering the different layers of meaning in the novel which is done through four successive readings. The first reading looks at the entertaining and aesthetic aspect of the novel. The second one pursues the line of satirical trend covered in the novel's artistic texture to criticise the culture, lifestyle and religious practices of the Persians. This section has focused on the critical look of the novel at the life of different classes of Persian society with the intention of doing corrections to the nation and its governing system. The third reading goes beyond the simplistic assumption of European benevolence toward the East, and signals the evidence testifying to the ideology of Orientalism and colonial discourse as the underlying layer of the story. This section, consequently, focuses upon the images displaying the Persian both as a felon and a veracious dimwit with a decadent 
culture, a despotic ruling system and a corrupt spiritual life. It brings to light the novelist's artistic efforts to accentuate the superiority of the colonizer upon the colonized and the latter's urgent need for being dominated and controlled by the Orientalists. The fourth reading investigates the discrepancies and the contradictions in the novel and its history of reception in terms of deviations from the objectives of Orientalist ideology. Notwithstanding the negative image of the nation presented in the satirical phase of the story, reading between the lines reveals ambivalence in the writer's look at the protagonist and the minor characters. The textual evidence from the primary and secondary sources shows that the colonial look upon the colonized is not homogeneously negative which renders E. W. Said's theory of 'Orientalist Discourse' insufficient as an all-encompassing critical aid. This finding, therefore, signifies the inevitability of incorporating a contributory theory such as Homi K. Bhabha's idea of 'ambivalence' as it admits and explains the vacillation of Orientalist discourse's attitude toward the colonized.

\section{References}

Aryanpour, Y. (1997). From Saba to Nima. Tehran: Sepehr Publications.

Bayat-Phillip, M. (1980) Mirza Agha khan Kirmani: A Nineteenth Century Nationalist. In E. Kedourie, \& S. G. Haim (Eds.), Towards a Modern Iran: Studies in thought, politics and society (pp. 64-96), London, England: Frank Gass.

Brydges, Sir H. J. (1834). An account of transactions of his majesty's mission to the court of Persia in year 1807-11 to which is appended a brief history of Wahauby, 2 vols. London: Longmans.

Morier, J. J. (1812). A journey through Persia, Armenia, and Asia Minor to Constantinople, in the year 1808 and 1809. London: Longmans.

Morier, J. J. (1985). The adventures of Haji Baba of Ispahan, London and New York: Macmillan and Co.

Said, E. (1979). Orientalism. New York: Random House.

Spur, D. (1993). The rhetoric of empire. Durham: Duke University press.

Tiffin, H., (1996). Post-colonial literatures and counter-discourse. In Ashcroft, B., G. Griffiths, and H. Tiffin (Eds.), Post-Colonial studies reader. London: Routledge.

\section{Notes}

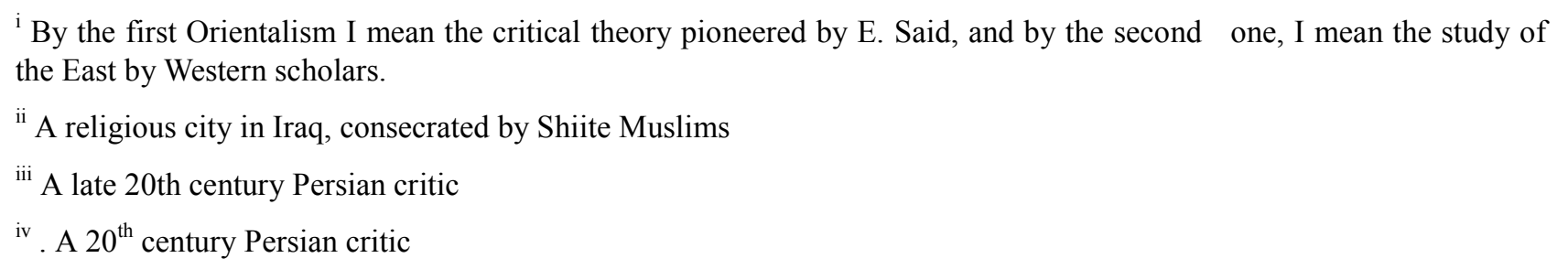

